\title{
Endovascular Superselective Embolization of the Prostatic Arteries in the Treatment of Benign Prostatic Hyperplasia
}

\author{
Ulan Zhaparov ${ }^{1 \star}$, Gafur Khairli ${ }^{1}$, Ulanbek Zhanbyrbekuly ${ }^{1}$, Alexei Sushchenko ${ }^{1}$, Yernur Ainayev ${ }^{1}$ \\ ${ }^{1}$ NJSC «Astana Medical University», KAZAKHSTAN \\ *Corresponding Author: astanaulan@mail.ru
}

Citation: Zhaparov U, Khairli G, Zhanbyrbekuly U, Sushchenko A, Ainayev Y. Endovascular Superselective Embolization of the Prostatic Arteries in the Treatment of Benign Prostatic Hyperplasia. Electron J Gen Med. 2021;18(3):em288. https://doi.org/10.29333/ejgm/10832

\begin{tabular}{|c|c|}
\hline ARTICLE INFO & ABSTRACT \\
\hline Received: 6 Feb. 2021 & Objective: The purpose of this study is to explore further a new minimally invasive method in order to expand the \\
\hline Accepted: 7 Apr. 2021 & $\begin{array}{l}\text { surgical options for treating patients with benign prostatic hyperplasia as well as to evaluate the efficacy and } \\
\text { safety of endovascular superselective embolization of prostatic arteries in patients with benign prostatic } \\
\text { hyperplasia. }\end{array}$ \\
\hline
\end{tabular}

Material and methods: The study group included 43 patients with benign prostatic hyperplasia, aged 56 to 90 years. The study carried out in the period from February to December 2019. All patients were determined by the level of prostate-specific antigen, ultrasound scan of the prostate and bladder, uroflowmetry, and used IPSS questionnaire. The physical condition of patients was assessed using the American Society of Anesthesiologists classification.

Results: The technical success of the operation in the form of bilateral embolization of prostatic arteries was achieved in $29(67.5 \%)$ patients. Unolateral embolization of prostatic arteries, due to the complex anatomical structure or atherosclerotic changes, were performed in 14 (32.5\%) patients. The observation period was from 3 to 6 months. According to uroflowmetry, the maximum urination rate the average value was $8.5 \pm 2.75 \mathrm{ml} / \mathrm{s}$. Six months after the operation the maximum volumetric urine flow rate during urination was on average $24.5 \pm 4.20$ $\mathrm{ml} / \mathrm{s}$.

Conclusion: Our results allow us to evaluate endovascular superselective embolization of prostatic arteries as an effective and safe method of treating lower urinary tract symptoms in men with benign prostatic hyperplasia, and can be introduced as a new promising and minimally invasive method for treating.

Keywords: benign prostatic hyperplasia, prostatic artery embolization, lower urinary tract symptoms

\section{INTRODUCTION}

X-ray endovascular super selective embolization of prostatic arteries (EPA) is currently considered as a perspective, minimally invasive method for treating patients with benign prostatic hyperplasia (BPH). The aim of our research was to introduce a new, less traumatic method and study the immediate and long-term results of EPA in patients with $\mathrm{BPH}$. The results obtained underline the high efficiency of EPA, both in reducing the symptoms of the lower urinary tract (LUTS) and improving the quality of life of patients, as well as a significantly lower percentage of complications compared to conventional surgical techniques.

Benign prostatic hyperplasia is one of the most common diseases among men over 40. According to the latest publications of some authors [1-4] in recent years, there has been an increase in the incidence of BPH in many countries of the world. According to statistical data, in Europe, the number of patients suffering from lower urinary tract symptoms caused by $\mathrm{BPH}$ varies depending on age - from $14 \%$ (40-49 years) to $40 \%$ (60-69 years), and histological signs of BPH in autopsy materials were identified in $60-80 \%$ of men aged 60 to 69 years [5,6]. About $10 \%$ of patients with $\mathrm{BPH}$ require surgery [7]. According to research indicators, in Russia there is a gradual increase in the frequency of BPH from $11.3 \%$ at the age of 40 49 years to $81.4 \%$ at the age of 80 years [8]. According to the statistical studies carried out in Kazakhstan, there is an increase in patients with benign prostatic hyperplasia. According to the data, in 2005, 2907 patients with BPH were registered, in 2009 - 3453 patients, which amounted to $18.7 \%$ of the increase in incidence [9]. Operative methods of treatment, such as transvesical adenomectomy, transurethral surgery in various modifications, are effective, however, they often have contraindications for those patients who have been diagnosed with severe concomitant pathology from the cardiovascular, respiratory, endocrine systems [8].

According to the European Association of Urology, the share of transurethral resection (TUR) of the prostate currently accounts for about $95 \%$ of all operations performed in patients with BPH [10]. However, having a high clinical efficiency, TURP of the prostate has a number of complications, which are detected in $25-67 \%$ of operated patients [11-14]. 
In 2010, a group of Portuguese researchers led by Pisco J.M. presented the results of a new treatment for BPH - prostatic artery embolization. The technique was performed in 15 patients with BPH and in 14 patients (93.3\%) was technically successful [15]. In parallel with the Portuguese scientists, in 2010 the works of Brazilian scientists were published under the head of Carnevale F. They successfully performed EPA 2 in patients with acute urinary retention that developed against the background of BPH [16].

In 2007, the State Program "Development of Cardiological and Cardiac Surgery for the Population of the Republic of Kazakhstan" was launched in Kazakhstan, and this became the starting point for the active development of domestic interventional surgery, within which specialized centers were opened in Astana, Almaty, Aktobe and Pavlodar. For the first time X-ray endovascular embolization was performed in 2006 at the National Scientific Center of Surgery named after Syzganov A. in the treatment of patients with uterine myoma [17]. Subsequently, according to the publications of many authors, embolization of the uterine arteries has received wide practical application in large medical centers in the treatment of cervical cancer and uterine fibroids [18-21]. In urological practice, embolization of prostatic arteries was introduced in 2012 on the basis of the Republican Scientific Center for Emergency Medical Aid. The team led by the head of the urology center Kutateladze G. for the first time successfully performed selective X-ray endovascular embolization of the prostatic arteries in a 70-year-old man with a prostate gland size of $104 \mathrm{~cm}^{3}$, who had contraindications to anesthetic and radical surgical intervention. Subsequently, the technique began to be applied in other medical centers of Kazakhstan.

Currently, X-ray endovascular surgery of benign prostatic hyperplasia has relatively little experience in treating patients with this pathology and needs further comprehensive study. In this publication, we have presented our own experience of using X-ray endovascular super selective embolization of prostatic arteries in the treatment of patients with benign prostatic hyperplasia.

\section{Purpose of the Study}

The purpose of this study is to explore further a new minimally invasive method in order to expand the surgical options for treating patients with $\mathrm{BPH}$ as well as to evaluate the efficacy and safety of X-ray endovascular super selective embolization of prostatic arteries in patients with $\mathrm{BPH}$.

\section{MATERIAL AND METHODS}

The study group included 43 patients with symptoms of the lower urinary tract caused by benign prostatic hyperplasia, aged 56 to 90 years. The study carried out in the period from February to December 2019. All patients, in addition to general clinical studies, were determined by the level of total and free prostate-specific antigen (PSA), transrectal ultrasound examination of the prostate gland (TRUS), ultrasound examination of the bladder with determination of the size of residual urine, uroflowmetry, excretory urography. During TRUS of the prostate, its size and dimension were measured, the structure and the presence of additional formations were assessed. Uroflowmetry was performed in patients admitted to the hospital in a planned manner in the absence of drainage of the lower urinary tract. During uroflowmetry, the following parameters were assessed: a urine volume, a maximum and average urination rate, time to reach maximum urine flow rate, uroflowmetric index and urination time. Intravenous urography made it possible to assess the excretory function of the upper urinary tract. The severity of lower urinary tract symptoms was assessed using the IPSS (International Prostate Symptom Score) scale, the patient's quality of life was assessed using the QoL (Quality of Life) scale. The examination by the anesthesiologist included a detailed assessment of the physical condition of patients before the surgery according to the classification of the American Society of Anesthesiologists (ASA). The above classification includes 5 classes of physical status: ASA I - healthy patient; ASA II - patient with mild systemic disease; ASA III - patient with severe systemic disease; ASA IV - a patient with a severe systemic disease, which is a constant threat to life; and ASA V - dying patient, vital indications surgery. Statistical processing of the obtained data carried out using the SPSS Statistics software from IBM, USA. The agreement of the local ethics committee for the study was obtained. All patients signed a voluntary, informed consent to the study.

The inclusion criteria for the study were:

- bladder outlet obstruction of moderate and severe severity according to the IPSS scale, caused by benign prostatic hyperplasia;

- the volume of the prostate gland is more than $40 \mathrm{~cm}^{3}$;

- contraindications for transurethral resection of the prostate gland.

At the stage of clinical follow-up of patients, certain contraindications to embolization of prostatic arteries were verified:

prostate cancer;

secondary stones of the bladder;

the volume of the prostate gland is less than $40 \mathrm{~cm}^{3}$;

renal failure;

intolerance to $x$-ray contrast agent;

atony of the bladder;

various coagulopathies;

acute urinary tract infection.

\section{Technique for Performing X-ray Endovascular}

\section{Superselective Embolization of Prostatic Arteries}

The operation is performed in an interventional X-ray operating room. In the absence of cystostomy drainage, all patients in the preoperative period were temporarily installed a Foley urethral catheter, the removal of which was carried out the next day after the patient was activated. In the supine position of the patient, after pretreatment of the operating field, under local anesthesia, puncture of the right common femoral artery was performed according to the Seldinger technique with a $5 \mathrm{Fr}(1.67 \mathrm{~mm})$ introducer inserted into the artery. Next, a Roberts catheter (uterine) is inserted into the contralateral common iliac artery. Abdominal aortography and serial pelvic angiography are performed. After vascular imaging, superselective catheterization is performed with a 2.4 $\operatorname{Fr}(0.8 \mathrm{~mm})$ microcatheter using a guidewire, 0.014 inch $(0.35$ $\mathrm{mm}$ ) in diameter, with arteriography of the prostatic branches of the inferior urinary artery. Under constant radiological control, the prostatic arteries are embolized with microspheres - 300-500 $\mu \mathrm{m}$ (microns). In the same way, the prostatic artery is embolized on the contralateral side. To objectively determine the effect of the operation, angiography of the vessels was repeated. In the case of a successful embolization, blocked 
Table 1. The number of hospitalized patients with and without cystostomy

\begin{tabular}{|c|c|c|c|c|c|}
\hline \multicolumn{2}{|c|}{ Hospitalized } & \multicolumn{2}{|c|}{ Absolute value } & \multicolumn{2}{|c|}{ Relative magnitude } \\
\hline \multirow{2}{*}{ Emergency } & with cystostomy & 2 & \multirow{2}{*}{26} & $4.7 \%$ & \multirow{2}{*}{$60.5 \%$} \\
\hline & without cystostomy & 24 & & $55.8 \%$ & \\
\hline \multirow{2}{*}{ Planned } & with cystostomy & 4 & \multirow{2}{*}{17} & $9.3 \%$ & \multirow{2}{*}{$39.5 \%$} \\
\hline & without cystostomy & 13 & & $30.2 \%$ & \\
\hline \multicolumn{2}{|c|}{ Total } & \multicolumn{2}{|c|}{43} & \multicolumn{2}{|c|}{$100 \%$} \\
\hline
\end{tabular}

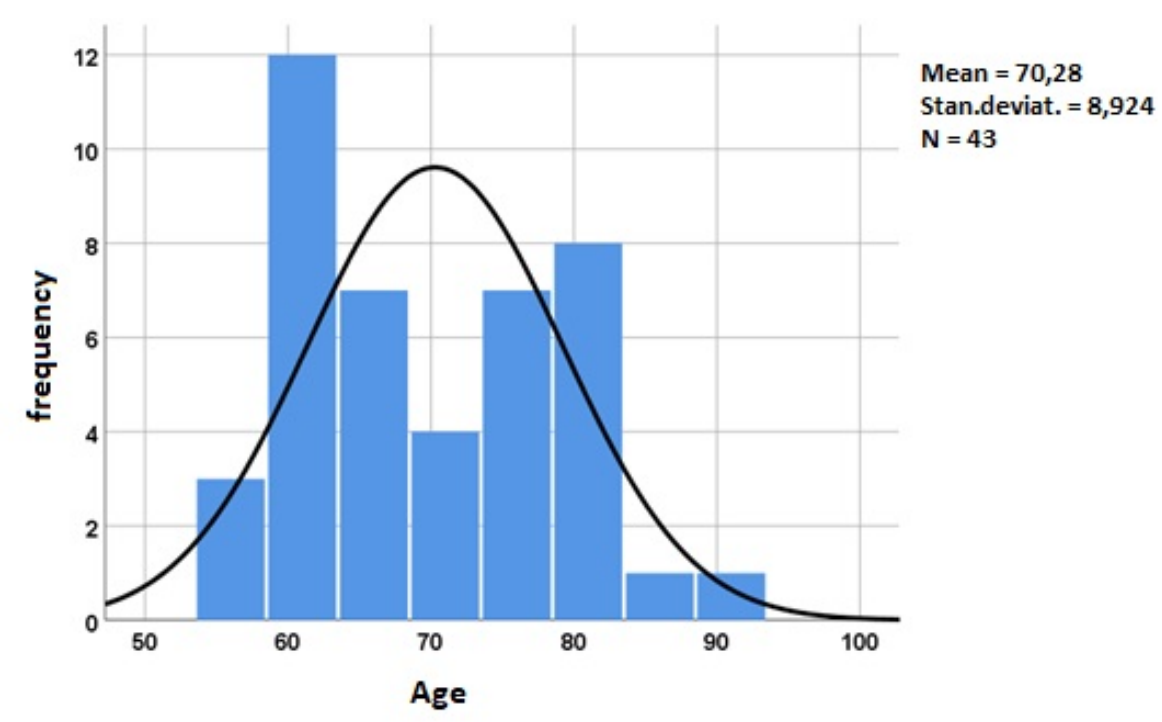

Diagram 1. Frequency of BPH occurrence by age

blood flow through the arteries of the prostate is visualized. After the manipulation, the diagnostic catheters are withdrawn, then the introducer is removed. A tight pressure bandage is applied to the puncture site. The duration of bed rest was 12 hours, after which the patient was allowed to get up.

In order to prevent the development of thromboembolic complications, all patients on the eve of the EPA procedure undergo a subcutaneous injection of $0.3 \mathrm{ml}$ fraxiparine and tight elastic bandaging of the lower extremities. In the postoperative period, all patients receive complex etiotropic, pathogenetic and symptomatic therapy. The selection of antibiotic therapy was carried out according to the results of the sensitivity of the bacterial urine culture. After discharge, all patients continued to take alpha-blockers for 3 to 6 months.

\section{RESULTS}

Most of the patients included in our study were hospitalized on an emergency basis - $26(60.5 \%)$ patients, of which $24(55.8 \%)$ patients were admitted with a clinical picture of acute urinary retention, $2(4.7 \%)$ patients had incompetence cystostomy drainage. Out of 43 patients, 17 (39.5\%) were hospitalized in a planned manner, of which 4 (9.3\%) patients had previously received a trocar cystostomy, 13 patients $(30.2 \%)$ were admitted with severe symptoms of bladder outlet obstruction. Among those hospitalized, 12 (27.9\%) patients underwent trocar cystostomy for absolute indications - 10 $(23.3 \%)$ of them were admitted on an emergency basis and 2 (4.7\%) were admitted as planned (Table 1 ).

According to Diagram 1 and Table 2, the average age of patients was 70.3 years. The average length of postoperative hospital stay was $4.84 \pm 2.06$ days. EPA was most often
Table 2. The main clinical and demographic indicators of patients

\begin{tabular}{ccc}
\hline Index & Mean & Range of values \\
\hline Age, years & $70.3 \pm 8.9$ & $56-90$ \\
\hline Postoperative day & $4.84 \pm 2.06$ & $1-12$ \\
\hline BMI, $\mathrm{kg} / \mathrm{m}^{2}$ & $27.2 \pm 5.6$ & $16.90-49.22$ \\
\hline IPSS, scores & $22.1 \pm 4.8$ & $11-30$ \\
\hline QoL, scores & $5.0 \pm 0.7$ & $3-6$ \\
\hline Total PSA, $\mathrm{ng} / \mathrm{ml}$ & $3.47 \pm 2.54$ & $1.01-9.6$ \\
\hline Free PSA, $\mathrm{ng} / \mathrm{ml}$ & $1.63 \pm 1.95$ & $0.23-11.39$ \\
\hline Prostate volume, $\mathrm{cm}^{3}$ & $72.1 \pm 23.1$ & $41-118$ \\
\hline Residual urine volume, $\mathrm{cm}^{3}$ & $228.1 \pm 268.6$ & $25-1200$ \\
\hline
\end{tabular}

performed in patients aged 60 (12 patients) and 80 years ( 8 patients). The average BMI of the patients was $27.2 \pm 5.6 \mathrm{~kg} /$ m2. $30(69.8 \%)$ patients were overweight, 12 (27.9\%) patients had grade I obesity, and 1 (2.3\%) had grade III obesity. The average indicators of the severity of symptoms of the disease and the quality of life of patients on the IPSS-QoL scale were $22.1 \pm 4.8$ and $5.0 \pm 0.7$ points, respectively, which was regarded as a severe severity with a significant impact on the quality of life. The minimum volume of the prostate gland according to TRUS, diagnosed in a 71-year-old patient with severe BPH symptoms, was $41 \mathrm{~cm} 3$. The average volume of the prostate gland was $72.1 \pm 23.1 \mathrm{~cm} 3$, with the highest value being 118 $\mathrm{cm} 3$.

Total and free prostate-specific antigen results varied. In the presence of cancer alertness, for the purpose of differential diagnosis with prostate cancer, multispiral computed tomography (MSCT) or magnetic resonance imaging (MRI) of the pelvic organs were performed on an outpatient basis. In some cases, the final verification of the diagnosis required a multifocal biopsy of the prostate. After confirming the diagnosis of $\mathrm{BPH}$, the patient was admitted to the hospital. Average PSA levels are presented in Table 2. 
Table 3. Indicators of uroflowmetry in the examined patients

\begin{tabular}{ccc}
\hline \multirow{2}{*}{ Index } & \multicolumn{2}{c}{ Mean (p<0,001) } \\
\cline { 2 - 3 } & Before surgery & After 6 months \\
\hline Urination volume, $\mathrm{ml}(\mathrm{V})$ & $223.3 \pm 114.5$ & $222.9 \pm 67.8$ \\
\hline $\begin{array}{c}\text { Average volumetric flow rate, } \\
\mathrm{ml} / \mathrm{s}(\mathrm{Q} a v g)\end{array}$ & $4.55 \pm 1.33$ & $16.98 \pm 4.51$ \\
\hline $\begin{array}{c}\text { Maximum volumetric flow rate, } \\
\mathrm{ml} / \mathrm{s}(\mathrm{Qmax})\end{array}$ & $8.5 \pm 2.75$ & $24.5 \pm 4.20$ \\
\hline Uroflow index (UI) & $0.54 \pm 0.15$ & $1.44 \pm 0.41$ \\
\hline Speed up the flow, $\mathrm{ml} / \mathrm{s}^{2}$ & $1.08 \pm 0.79$ & $9.76 \pm 5.23$ \\
\hline Time of urination, $\mathrm{s}(\mathrm{T})$ & $43.0 \pm 27.7$ & $18.38 \pm 4.66$ \\
\hline Time to reach Qmax, $\mathrm{s}(\mathrm{TQmax})$ & $12.2 \pm 8.4$ & $7.38 \pm 2.96$ \\
\hline
\end{tabular}

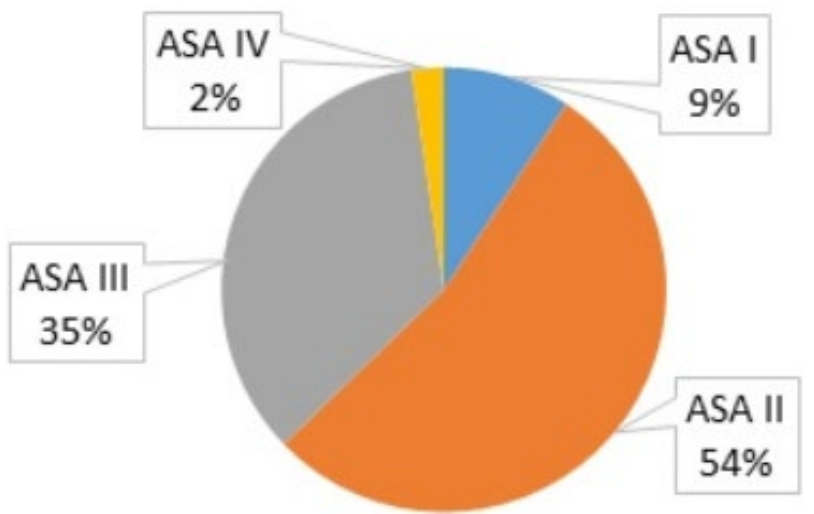

Diagram 2. Physical status of patients according to the ASA classification
According to uroflowmetry, the maximum urination rate ranged from 4.4 to $14.7 \mathrm{ml} / \mathrm{s}$, and on average $8.5 \pm 2.75 \mathrm{ml} / \mathrm{s}$, the average volumetric urine flow ranged from 3.1 to $7.6 \mathrm{ml} / \mathrm{s}$, on average $4.55 \pm 1.33 \mathrm{ml} / \mathrm{s}$, urination time ranged from 7.0 to $102.1 \mathrm{~s}$, the average value was $43.0 \pm 27.7 \mathrm{~s}$. The average value of urine volume during urination was $223.3 \pm 114.5 \mathrm{ml}$, ranging from 97 to $561 \mathrm{ml}$. The uroflow index before surgery averaged $0.54 \pm 0.15$. Six months after the operation, the maximum volumetric urine flow rate during urination was on average 24.5 $\pm 4.20 \mathrm{ml} / \mathrm{s}$, the average urinary volumetric flow rate was 16.98 $\pm 4.51 \mathrm{ml} / \mathrm{s}$. The average uroflow index improved to $1.44 \pm 0.41$ (Table 3).

According to the ASA classification, all patients were divided as follows: I class - in 4 patients, II class - in 23 patients, III and IV classes - in 15 and 1 patients, respectively (Diagram 2).

The technical success of the operation in the form of bilateral EPA was achieved in 29 (67.5\%) patients, while in one patient bilateral EPA was performed in two stages due to technical difficulties during selective catheterization of the prostatic artery on the left. Unolateral EPA, due to the complex structure of the branches of the internal iliac artery, or atherosclerotic changes in the vessels, was performed in 9 (20.9\%) patients on the left and in $5(11.6 \%)$ patients on the right. The average duration of the operation was $36.6 \pm 13.6$ minutes (ranged from 15 to 90 minutes). The main stages of a successfully performed bilateral EPA are shown in Figure 1.
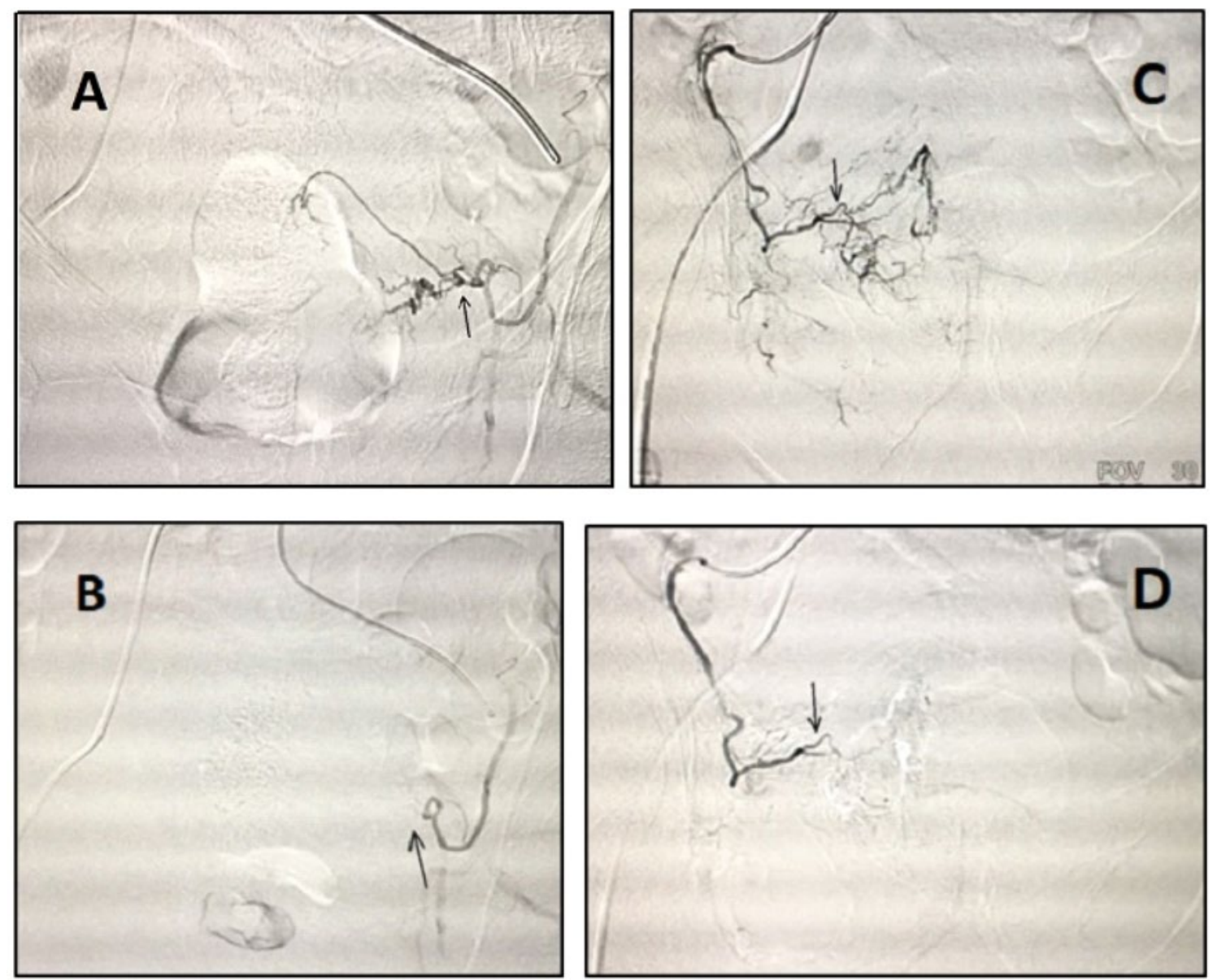

Figure 1. Stages of bilateral EPA: A - selective angiography of the left internal iliac artery (the arrow indicates the branches of the prostatic artery); $\mathbf{B}$ - the arrow indicates the block of the left artery of the prostate gland; C - selective angiography of the right internal iliac artery (the arrow indicates the branches of the prostatic artery); $\mathbf{D}$ - the arrow indicates the block of the right artery of the prostate gland 
Table 4. Developed postoperative complications according to the Clavien-Dindo classification

\begin{tabular}{cc}
\hline Complication rate & Number of cases \\
\hline $\mathrm{I}$ & $20(46.5 \%)$ \\
\hline $\mathrm{II}$ & - \\
\hline $\mathrm{IIla}$ & $2(4.7 \%)$ \\
\hline $\mathrm{IIIb}$ & $1(2.3 \%)$ \\
\hline $\mathrm{IVa}$ & - \\
\hline $\mathrm{IVb}$ & $1(2.3 \%)$ \\
\hline $\mathrm{V}$ & -
\end{tabular}

One of the important results of our work was the distribution of postoperative complications according to the Clavien-Dindo classification (Table 4). According to this classification, 5 degrees of complications are subdivided, where:

I degree - any deviations from the normal postoperative course that do not require medication or surgical, endoscopic, radiological intervention. Therapeutic treatment is allowed: antipyretics, analgesics, diuretics, electrolytes, physiotherapy. This also includes the treatment of wound infections;

II degree - requires treatment in the form of blood transfusion, enteral or parenteral nutrition;

III degree - surgical, endoscopic or radiological intervention is required: IIla - intervention without general anesthesia; IIIb intervention under general anesthesia;

IV degree - life-threatening complications (including complications from the central nervous system) requiring intensive care, observation in the intensive care unit, organ resection: IVa - failure of one organ; IVb - multiple organ failures;

$\mathrm{V}$ - death of the patient.

In the early postoperative period, 14 (32.6\%) patients had dysuric disorders in the form of pollakiuria, stranguria, which did not require additional treatment. $6(14 \%)$ patients had pain in the perineal region. Pain syndrome in these patients was stopped by taking oral NSAIDs for 3-5 days. In one case (2.3\%), on the 2nd day after EPA, the patient developed acute urinary retention, requiring the installation of a cystostomy drainage, which was subsequently removed after 1 month. It should be noted that in $1(2.3 \%)$ patient, on the 1st day after the operation, the pain syndrome was clinically manifested in the form of an acute abdomen. However, such a formidable complication after an additional examination and examination of the surgeon was excluded. The patient was discharged on the 7th day after the operation in a satisfactory condition. 3 weeks after the operation, the patient returned with complaints of abdominal pain. Computed tomography of the abdominal segment and pelvic organs revealed a prostate abscess. The patient underwent the second stage operation transurethral resection of the prostate. The postoperative period was uneventful. The urethral catheter was removed on the 4th day after the operation, spontaneous urination was restored with a satisfactory stream, no pain was observed. In 1 $(2.3 \%)$ patient in the early postoperative period, the development of acute ischemic balanitis was noted. The patient was under outpatient supervision for 2 months, longterm conservative therapy gave a positive result, the treatment ended in recovery. $1(2.3 \%)$ patient who had a high anesthetic risk developed submassive, bilateral thromboembolism of the left main pulmonary artery, left lower lobe arteries, segmental lower lobe arteries on the right side on the 1st day after the operation. Timely diagnostics and emergency cardiopulmonary resuscitation with further active thrombolytic therapy stabilized the patient's hemodynamic parameters. The patient was transferred to the somatic department. Subsequently, after being discharged, he was under the simultaneous supervision of a therapist and a cardiologist.

The immediate results were tracked in all patients included in the study. The observation period was from 3 to 6 months. Among 16 cases of the presence of cystostomy drainage, followed by removal 2 months after EPA, adequate recovery of spontaneous urination was noted in 11 patients $(68.8 \%$ of all patients with cystostomies). Evaluation of the effectiveness of the performed operation was carried out 3 months after EPA by filling in the IPSS and QoL questionnaires. In 38 (88.4\%) patients, there was a persistent subjective improvement in urination (the mean IPSS was $11.3 \pm 1.2$ points) and an improvement in the quality of life $-2.4 \pm 0.5$ points. After 6 months, these indicators were $8.7 \pm 0.9$ and $1.9 \pm 0.4$ points, respectively (Diagram 3 ).

Out of 5 cases, despite a significant regression of the volume of the prostate gland, independent urination did not recover in $3(7 \%)$ patients, due to a cystostomy that developed against the background of prolonged drainage of the urinary bladder.

$1(2.3 \%)$ patient had EPA performed on the one side; however, due to a slight regression of the volume of the

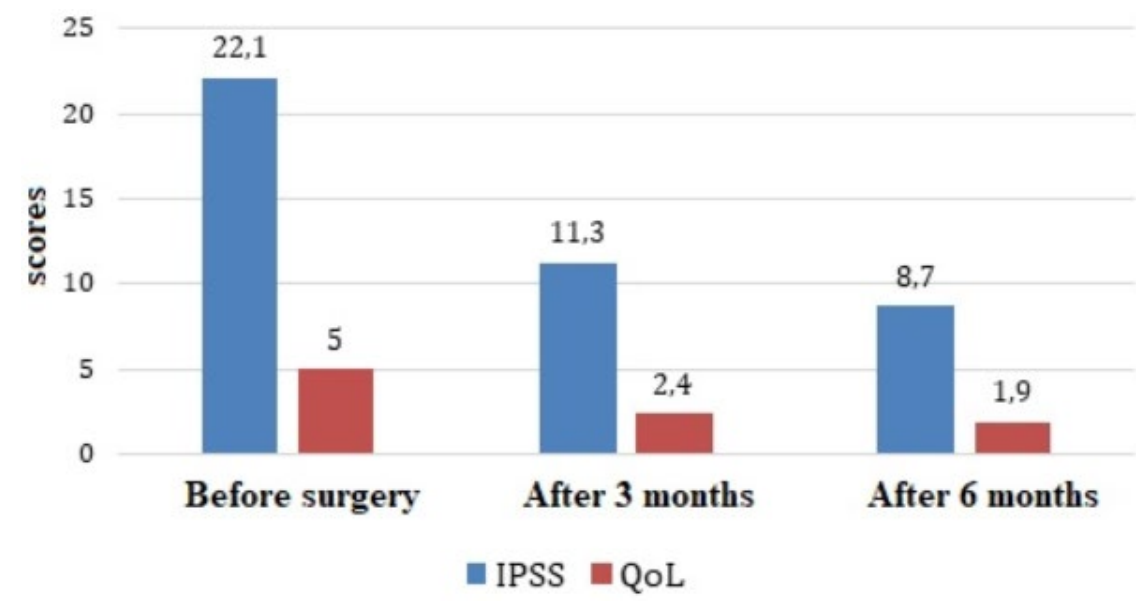

Diagram 3. Dynamics of IPSS and QoL indices in the studied patients 3 AND 6 months after surgery $(n=43)$ 
prostate gland and the presence of a decompensated stage of cardiovascular pathology, it was decided to refrain from further manipulations and to maintain constant drainage of the bladder with a cystostomy. One patient dropped out of the study after 5 months due to a verified diagnosis of brain cancer.

\section{DISCUSSION}

We have analyzed the results of treatment of patients with moderate and severe symptoms of the lower urinary tract caused by benign prostatic obstruction, as well as those who do not have a high anesthetic risk, using X-ray endovascular super selective embolization of prostatic arteries. The technique was first described in 2000 by John S. DeMeritt and co-authors using microcatheter technique to a 76-year-old patient with conservatively persistent massive hematuria that developed against BPH in order to stop bleeding. The authors noted the volume of the prostate gland was $305 \mathrm{ml}$, the level of total PSA was $40 \mathrm{ng} / \mathrm{ml}$, histological examination showed no signs of malignancy. Superselective catheterization of the right lower urinary artery was performed, followed by the introduction of polyvinyl acetate particles with a diameter of 150-250 $\mu \mathrm{m}$. In the early postoperative period, the patient had an immediate stop of hematuria, as well as a significant improvement in urination. The volume of the prostate gland 2 months after EPA was $235 \mathrm{ml}$, after 5 months - $160 \mathrm{ml}$, after 1 year $-190 \mathrm{ml}$. PSA levels dropped to $4 \mathrm{ng} / \mathrm{ml}$ by the 5 th month after EPA. The authors noted that the patient's sexual function after EPA did not change [22].

Despite such a success of EPA in the treatment of patients with $\mathrm{BPH}$, interest in the technique from the professional community of urologists appeared only in 2008, when experimental work on laboratory animals was first published, in which the effect of EPA on the size of the prostate gland was evaluated $[23,24]$.

In 2010, Russian researchers Yakovets E, Neimark A, Karpenko A presented data on prostatic artery embolization in 40 patients with high anesthetic risk. According to the results of the study, after the operation there was a marked clinical improvement in dysuric symptoms, a decrease in the volume of the prostate gland by $50 \%$ and the volume of the adenomatous node by $43 \%$ [21]. The technique of X-ray endovascular superselective embolization of the arteries of the prostate is a new minimally invasive, safer and more effective method of surgical treatment of patients with BPH $[25,26]$.

Among the domestic publications there are works of such authors as Kurmangaliev O., Sartaev E., Tabynbaev N. (2017), who also noted the effectiveness and safety of EPA in the treatment of patients with $\mathrm{BPH}$.

Several scientific works have proven that EPA affects the pathogenetic components of obstruction in LUTS. The bottom line is that as a result of ischemic infarction of adenomatous tissues, increased apoptosis, as a secondary effect of local hypoxia, the volume of the prostate gland decreases, and the titer of unconjugated intravesical testosterone decreases and, as a consequence, the termination of its transformation into dihydrotestosterone in the prostate tissues. EPA leads to a decrease in the tone of smooth muscle cells of a1-adrenergic receptors, which has a positive effect on the urodynamic component of LUTS $[16,27,28]$.
It is important to note that one of the main obstacles to the routine use of EPA remains the continuing risk of embolization of non-target arteries, leading to the development of ischemia of the pelvic organs, primarily of the rectum and bladder, as well as the penile arteries [29]. However, modern methods of additional pre- and intraoperative imaging can minimize the risk of these complications.

To date, centers located in Portugal, Brazil, USA, China, France and Russia are developing most actively in the application of the EPA method in the world. At the International Society of Interventional Radiologists, EPA is regarded as a new promising and effective method of treating patients with $\mathrm{BPH}$ with a high level of safety. However, for the routine treatment of BPH, further comprehensive scientific study of the early and long-term results of treatment is necessary [30].

\section{CONCLUSIONS}

Our results allow us to evaluate X-ray endovascular superselective embolization of prostatic arteries as an effective and safe method of treating lower urinary tract symptoms in men with benign prostatic hyperplasia.

The increase in uroflowmetric parameters, such as the maximum and average volumetric urination rate, as well as the uroflow index, is statistically significant. In addition, 6 months after the X-ray endovascular superselective embolization of the prostatic arteries, the symptoms of the lower urinary tract on the IPSS scale significantly decreased, which had a positive effect on the quality of life of the patients. Embolization of prostatic arteries can be performed in patients without severe intercurrent diseases, as well as in patients with cystostomy and acute urinary retention.

Embolization of prostatic arteries can be introduced as a new promising and minimally invasive method for treating patients with $\mathrm{BPH}$, as an alternative to historeduction interventions on the prostate gland.

Author contributions: All authors have sufficiently contributed to the study, and agreed with the results and conclusions.

Funding: No funding source is reported for this study.

Declaration of interest: No conflict of interest is declared by authors.

\section{REFERENCES}

1. Al-Rawashdah SF, Pastore AL, Salhi YA, Fuschi A, Petrozza V, Maurizi A, Illiano E, Costantini E, Palleschi G, Carbone A. Prospective randomized study comparing monopolar with bipolar transurethral resection of prostate in benign prostatic obstruction: 36-month outcomes. World journal of urology, 2017;35(10):1595-601. https://doi.org/10.1007/ s00345-017-2023-7 PMid:28243790

2. Füllhase C. Die transurethrale Resektion der Prostata [Transurethral resection of the prostate]. Der Urologe. Ausg. A, 2016;55(11):1433-9. https://doi.org/10.1007/ s00120-016-0243-x PMid:27680972

3. Suchshenko A, Sadykov A. Study of urodynamics in patients with benign prostatic hyperplasia after transurethral resection. Astana. Astana medical university. Materials of the conference of young scientists, 2013:254-5. 
4. Martov AG, Kornienko SI, Gushchin BL, Ergakov DV, Sazonov OA. Intraoperative urological complications in transurethral surgical interventions on the prostate for benign hyperplasia. Urologiia (Moscow, Russia: 1999), 2005;(4):3-8. https://pubmed.ncbi.nlm.nih.gov/16158736

5. Emberton M, Andriole GL, de la Rosette J, Djavan B, Hoefner $\mathrm{K}$, Vela Navarrete R, et al. Benign prostatic hyperplasia: a progressive disease of aging men. Urology, 2003;61(2):26773. https://doi.org/10.1016/s0090-4295(02)02371-3

6. Logie JW, Clifford GM, Farmer RD, Meesen BP. Lower urinary tract symptoms suggestive of benign prostatic obstruction--Triumph: the role of general practice databases. European urology, 2001;39(Suppl 3):42-7. https://doi.org/10.1159/000052567 PMid:11275742

7. Lourenco T, Pickard R, Vale L, Grant A, Fraser C, MacLennan G, N'Dow J, Benign Prostatic Enlargement team. Minimally invasive treatments for benign prostatic enlargement: systematic review of randomised controlled trials. BMJ (Clinical research ed.), 2008;337:a1662. https://doi.org/ 10.1136/bmj.a1662 PMid:18845591 PMCid:PMC2565752

8. Aliaev I, Rapoport LM, Vinarov AZ, Tsarichenko DG. Transuretral'naia élektrokhirurgiia $v \quad l$ lechenii dobrokachestvennoľ giperplazii predstatel'nol zhelezy [Transurethral electrosurgery in the treatment of benign prostatic hyperplasia]. Khirurgiia, 2001;(4):39-42. https://pubmed.ncbi.nlm.nih.gov/11490490

9. Shalekenov BU, Kuandykov EA. Application release active antibodies in complex treatment of patients with benign prostatic hyperplasia. Andrology and genital surgery, 2015;(2):65-8. https://doi.org/10.17650/2070-9781-2013-2 65-68

10. Tkachuk IN. Complications of transurethral resection of the prostate in patients with benign prostatic hyperplasia and ways of their prevention. Dissertation. Candidate of Medical Sciences. St. Petersburg. 2014. Available at: http://medical-diss.com/docreader/327833/a?\#?page=1

11. Koroteev MA, Korenkov DG. Prevention of exacerbations of concomitant infectious and inflammatory diseases after transurethral resection of benign prostatic hyperplasia. Military Medical Journal. 2018;329(2):66-7. Available at: https://www.elibrary.ru/item.asp?id=9940319

12. Loran OB, Luk'ianov IV, Markov AV. Combined therapy of voiding irritative disorders after surgical treatment of benign prostatic hyperplasiawith Andro-gin. Urologiia (Moscow, Russia: 1999), 2005;(3):15-8. Available at: https://pubmed.ncbi.nlm.nih.gov/16097707

13. Patel A, Fuchs GJ, Gutierrez-Acéves J, Andrade-Peréz F. Transurethral electrovaporization and vapour-resection of the prostate: an appraisal of possible electrosurgical alternatives to regular loop resection. BJU international, 2000;85(2):202-10. https://doi.org/10.1046/j.1464-410x. 2000.00463.x PMid:10671868

14. Power RE, Fitzpatrick JM. Medical Treatment of BPH: An Update on Results. Eur. Urol., 2004;2(1):6-13. https://doi.org/10.1016/j.euus.2004.01.003

15. Notov KG, Kim GV, Dobryak AY, Sazanova ID, Domakhin IA, Kovrov IV, Felikov IM. Results of embolization of prostate arteries - method of surgical treatments at benign hyperplasias of prostate. Journal of Siberian Medical Sciences, 2013;(5). Available at: https://cyberleninka.ru/ article/n/rezultaty-embolizatsii-arteriy-prostaty-metodahirurgicheskogo-lecheniya-dobrokachestvennoygiperplazii-prostaty
16. Carnevale FC, Antunes AA, da Motta Leal Filho JM, de Oliveira Cerri LM, Baroni RH, Marcelino AS, Freire GC, Moreira AM, Srougi M, Cerri GG. Prostatic artery embolization as a primary treatment for benign prostatic hyperplasia: preliminary results in two patients. Cardiovascular and interventional radiology, 2010;33(2):355-61. https://doi.org/10.1007/s00270-0099727-z PMid:19908092 PMCid:PMC2841280

17. Kasymbekova FD, Espaeva RN, Nugmanova MI, Medet BB. Uterine artery embolization as a treatment for uterine fibroids (review). Scientific-Practical Journal of Medicine, "Vestnik KazNMU", 2015;1:22-5. Available at: https://cyber leninka.ru/article/n/embolizatsiya-matochnyh-arteriykak-metod-lecheniya-miomy-matki-obzor-literatury

18. Abishev BKh, Aliakparova MT, Tazhibaev DM, Pitel ES. Longterm results of uterine artery embolization in uterine myoma according to ultrasound and magnetic resonance imaging. Russian Journal of Woman and Child Health, 2014;14:1020-2. Available at: https://www.rusmedreview. com/articles/ginekologiya/otdalennye-rezultatyembolizatsii-matochnykh-arteriy-pri-miome-matki-podannym-ultrazvukovogo-issled/

19. Korkan Al, Kasenova DA. Endovascular embolization of uterine vessels as a method of treating uterine fibroids in women of reproductive age. Reproductive medicine, 2011;(1-2):6-7. Available at: https://cyberleninka.ru/article/ n/embolizatsiya-matochnyh-arteriy-kak-metod-lecheniyamiomy-matki-obzor-literatury

20. Mahmutov NT, Bainazarova AA, Yakubova MB, Kulakeev OK, Ygai KV, Aribzhanov DT. Embolization uterine artery in treatment of patients with cervical cancer. Medical science and education of the Urals, 2009;10(3):106-8. Available at: https://cyberleninka.ru/article/n/embolizatsiyamatochnyh-arteriy-pri-lechenii-bolnyh-rakom-sheykimatki

21. Yakubova MB, Bajnazarova AA, Ormanov NK. Uterine artery embolization, applications in the treatment of cancer of the cervix. Medical science and education of the Urals, 2012;13(2):128-9. Available at: https://www.elibrary.ru/ item. asp?id=22584317

22. DeMeritt JS, Elmasri FF, Esposito MP, Rosenberg GS. Relief of benign prostatic hyperplasia-related bladder outlet obstruction after transarterial polyvinyl alcohol prostate embolization. Journal of vascular and interventional radiology: JVIR, 2000;11(6):767-70. https://doi.org/10.1016 /s1051-0443(07)61638-8

23. Mauro MA. Can hyperplastic prostate follow uterine fibroids and be managed with transcatheter arterial embolization?. Radiology, 2008;246(3):657-8. https://doi.org/10.1148/ radiol.2463071721 PMid:18309010

24. Sun F, Sánchez FM, Crisóstomo V, Lima JR, Luis L, GarcíaMartínez V, López-Sánchez C, Usón J, Maynar M. Benign prostatic hyperplasia: transcatheter arterial embolization as potential treatment--preliminary study in pigs. Radiology, 2008;246(3):783-9. https://doi.org/10.1148/ radiol.2463070647 PMid:18223124

25. Carnevale FC, Antunes AA. Prostatic artery embolization for enlarged prostates due to benign prostatic hyperplasia. How I do it. Cardiovascular and interventional radiology, 2013;36(6):1452-63. https://doi.org/10.1007/s00270-0130680-5 PMid:23903785 
26. Martins Pisco J, Pereira J, Rio Tinto H, Fernandes L, Bilhim T. How to perform prostatic arterial embolization. Techniques in vascular and interventional radiology, 2012;15(4):286-9. https://doi.org/10.1053/j.tvir.2012.09.002 PMid:23244725

27. Kurbatov D, Russo GI, Lepetukhin A, Dubsky S, Sitkin I, Morgia G, Rozhivanov R, Cimino S, Sansalone S. Prostatic artery embolization for prostate volume greater than 80 cm3: results from a single-center prospective study. Urology, 2014;84(2):400-4. https://doi.org/10.1016/ j.urology.2014.04.028 PMid:24929948

28. Pisco J, Campos Pinheiro L, Bilhim T, Duarte M, Rio Tinto H, Fernandes L, Vaz Santos V, Oliveira AG. Prostatic arterial embolization for benign prostatic hyperplasia: short- and intermediate-term results. Radiology, 2013;266(2):668-77. https://doi.org/10.1148/radiol.12111601 PMid:23204546
29. Antunes AA, Carnevale FC, da Motta Leal Filho JM, Yoshinaga EM, Cerri LM, Baroni RH, Marcelino AS, Cerri GG, Srougi M. Clinical, laboratorial, and urodynamic findings of prostatic artery embolization for the treatment of urinary retention related to benign prostatic hyperplasia. A prospective single-center pilot study. Cardiovascular and interventional radiology, 2013;36(4):978-86. https://doi.org /10.1007/s00270-013-0611-5 PMid:23580116

30. McWilliams JP, Kuo MD, Rose SC, Bagla S, Caplin DM, Cohen EI, Faintuch S, Spies JB, Saad WE, Nikolic B, Society of Interventional Radiology. Society of Interventional Radiology position statement: prostate artery embolization for treatment of benign disease of the prostate. Journal of vascular and interventional radiology: JVIR, 2014;25(9):1349-51. https://doi.org/10.1016/ j.jvir.2014.05.005 PMid:24993818 